\title{
ENTREPRENEURS AS INTERMEDIARIES
}

\author{
Mike W. Peng * \\ University of Texas at Dallas \\ Jindal School of Management \\ 800 West Campbell, SM 43 \\ Richardson, TX 75080
}

Tel: (972) 883-2714 / Fax: (972) 883-6029

mikepeng@utdallas.edu /www.mikepeng.com

\author{
Seung-Hyun Lee \\ University of Texas at Dallas \\ Jindal School of Management \\ 800 West Campbell, SM 43 \\ Richardson, TX 75080
}

Tel: (972) 883-6267 / Fax: (972) 883-2799

lee.1085@utdallas.edu

\author{
Sungjin J. Hong \\ Queen's University Management School \\ Riddel Hall 01.022 \\ 185 Stranmillis Road, Belfast BT9 5EE, UK \\ Tel: +44-28-9097-4508 \\ s.hong@qub.ac.uk \\ Forthcoming, Journal of World Business \\ February 2013 (estimated to appear in 2014)
}

* Corresponding author

[Acknowledgment $]$ We thank John Slocum (editor) and two reviewers for their guidance, and Dane Blevins, Omer Gokalp, Sergey Lebedev, Craig Macaulay, Canan Mutlu, Steve Sauerwald, Ciprian Stan, Weichieh Su for their helpful comments. This research was supported in part by a National Science Foundation CAREER Grant (SES 0238820) and the Jindal Chair at UT Dallas. The views are ours and not necessarily those of the underwriters. 


\section{Entrepreneurs as Intermediaries}

\section{[Abstract]}

This paper sketches the contours of a theory of entrepreneurship focusing on the nature of entrepreneurship as intermediation under information asymmetries. While entrepreneurship, strategy, and finance researchers have studied the relationship between entrepreneurs and intermediaries, they tend to treat intermediaries, such as venture capitalists, as a separate organizational form that is parallel with (start-up) entrepreneurs. In this paper, we consider entrepreneurs as intermediaries who discover, create, and exploit entrepreneurial opportunities by bearing uncertainties stemming from intermediation between potential buyers and sellers under information asymmetries. Specifically, we focus on two key questions in entrepreneurship research: (1) Why do entrepreneurs arise and exist at all? (2) Why do some entrepreneurs perform better than others in creating entrepreneurial opportunities, and ultimately creating wealth? Our discussion culminates in a new research agenda with four testable propositions. 


\section{INTRODUCTION}

"Both history of science and creativity research have shown that reformulating the questions we ask can lead to breakthroughs more often than trying harder to search for more rigorous answers" (Sarasvathy, 2004: 707). In search of such a more creative spirit, we in this paper advance the argument that the nature of entrepreneurship can be viewed from a new angle-intermediation, which is an entrepreneurial role critical in discovering and creating entrepreneurial opportunities. In the past literature, entrepreneurship has traditionally been defined as "the discovery, evaluation, and exploitation of future goods and services" (Eckhardt \& Shane, 2003; Venkataraman, 1997). In light of this definition, both opportunity discovery theory and opportunity creation theory have addressed two key questions centered on the nature of entrepreneurship (Amit, Glosten, \& Muller, 1993; Foss, Klein, Kor, \& Mahoney, 2008): (1) Why do entrepreneurs arise and exist? (2) Why do some entrepreneurs perform better than others in creating opportunities, adding value, and creating wealth?

While there are many different ways of conceptualizing entrepreneurial firms, past research tends to look at new start-ups as entrepreneurial firms (Aldrich, 1999; Katz \& Gartner, 1988). However, not all new firms discover, exploit, and create new goods or services that can add value to the economy (Schumpeter, 1934). In that sense, we argue that entrepreneurship research may be able to use a little different definition of entrepreneurs - individuals and/or organizations that discover and create entrepreneurial opportunities somewhere in the value chain in an industry—rather than the traditional definition of "start-up" firms.

Our argument is based on classical insights of Austrian economics (Kirzner, 1973; Schumpeter, 1934; von Mises, 1949), which classifies five representative types of entrepreneurial opportunities as (1) creating a new product, (2) creating a new method of production, (3) discovering a new market, (4) discovering or creating a new production factor, and (5) creating a new organizational form or industry (Schumpeter, 1934). In order for entrepreneurs to discover or create these entrepreneurial opportunities, 
they have to bear uncertainties stemming from their opportunity discovery/creation efforts (Klein, 1999). A major way that entrepreneurs bear uncertainties is intermediating between potential buyers and sellers in the value chain, since buyers and sellers may neither be willing to bear uncertainties stemming from opportunities nor have the abilities to discover or create opportunities (Kirzner, 1997; Klein, 1999; von Mises, 1949).

In the past literature, opportunity discovery theory posits that entrepreneurs can add value by exploiting exogenously given opportunities in pre-existing markets (Kirzner, 1997; Shane \& Venkatraman, 2000), while opportunity creation theory claims that entrepreneurs add value by endogenously creating new market opportunities (Aldrich, 1999; Baker \& Nelson, 2005; Sarasvathy, 2001). Despite the significant progress in our understanding of discovering and creating entrepreneurial opportunities, we still have limited knowledge on how entrepreneurs discover or create opportunities by taking advantages of information asymmetries in markets (Fiet, 2007). The processes that entrepreneurs discover and create entrepreneurial opportunities thus have remained as a gap to be filled in entrepreneurship research (Klein, 2008).

In response, this paper extends current theories by arguing that the nature of entrepreneurship can be viewed as intermediation. We accomplish this by focusing on three questions extended from key questions of entrepreneurship: (1) How do entrepreneurs add value in the value chain via intermediation? (2) Under what conditions would entrepreneurs be better able to exploit pre-existing opportunities via intermediation? (3) Under what conditions would entrepreneurs be better able to create new opportunities via intermediation?

Why is the "intermediation" perspective useful to push entrepreneurship research further? Three reasons emerge. First, it is because entrepreneurs, by definition, are individuals and/or organizations that add value in the process of enacting and exploiting entrepreneurial opportunities (Brandenburger \& Stuart, 1996; Foss et al., 2008). Capturing economic value by discovering and 
creating opportunities always bring uncertainties to people who are willing and able to bear uncertainties to connect their potential buyers and sellers (Klein, 1999; von Mises, 1949). Second, it is because some entrepreneurs choose to play intermediation roles because they believe they are better able to discover and create opportunities when there are information asymmetries between buyers and sellers in the value chain (Spulber, 2009). Third, compared to the traditional definition of entrepreneurship, the intermediation concept broadens the scope of entrepreneurs. We can reinterpret intermediary entrepreneurs, such as venture capitalists, with this new angle.

To be sure, entrepreneurship, strategy, and finance researchers are familiar with specialized intermediaries such as venture capital firms. However, researchers tend to focus on the relationship between intermediaries and (start-up) entrepreneurs, thus implicitly treating intermediaries such as venture capitalists as a separate organizational form that is parallel with (start-up) entrepreneurs (Lim $\& \mathrm{Cu}, 2012)$. As a result, while the strategies and performance of venture capitalists have been explored to a certain extent, the bulk of entrepreneurship research has concentrated on the other side of this relationship—namely, "entrepreneurs" who are, by default, not intermediaries. This paper departs from the existing literature by arguing that it is beneficial to view intermediaries as entrepreneurs. In other words, venture capitalists themselves can be conceptualized—and should be studied—as entrepreneurs (Klein, 1999; Wasserman, 2002).

The objective of this paper, however, goes substantially beyond merely labeling venture capitalists as entrepreneurs. We argue that, under information asymmetries, many entrepreneurs who attempt to discover and create entrepreneurial opportunities achieve their goals by intermediating between buyers and sellers in the value chain. We suggest that a more parsimonious and testable theory that can define entrepreneurship in a broader way is to view entrepreneurs as intermediaries who discover and create entrepreneurial opportunities stemming from information asymmetries and market failures. In addition, we propose boundary conditions that entrepreneurs discover and create 
entrepreneurial opportunities through intermediation, drawing on two leading theories in the literature: transaction cost economics (TCE) and the resource-based view (RBV). TCE and RBV are relevant theoretical perspectives for our arguments because both assume entrepreneurs' act of uncertaintybearing is a key driver in the entrepreneurial process.

\section{WHAT ARE INTERMEDIARIES?}

According to the economics of market microsturcture, an intermediary is an economic player who "helps buyers and sellers meet and transact" (Spulber, 1999: 3). In general, intermediaries add value by “transporting, storing, repackaging, assembling, preparing for final use, and adding information and guarantees" (Spulber, 1996: 136). We extend this definition of intermediation in a broader sense. We define intermediaries as individuals and/or organizations that position themselves somewhere on the value chain and that make efforts to discover or create entrepreneurial opportunities by bearing uncertainties that their potential buyers and sellers would be neither willing nor able to bear.

With this broader definition, intermediaries can add value by brokering between buyers and sellers under the condition of information asymmetries-in other words, making markets (Cantillon, 1959). For example, Amazon.com has created a new market space by utilizing the emergence of the Internet. Before Amazon.com emerged as an online commerce intermediary, other incumbents were already arbitraging information asymmetries between book buyers and sellers. What really happened is "re-intermediation.” Basically Amazon, as a new intermediary, has emerged to displace some incumbents and created a new market space with a new set of distribution channels (i.e., new meansends relationship) that reduced transaction costs between buyers and sellers, resulted in the creation of entrepreneurial rents (Anderson \& Anderson, 2002).

In addition, "traditional" intermediaries are known to exist in sectors whereby information asymmetries between buyers and sellers of goods and services are strong (Akerlof, 1970), such as 
financial markets and international trade. In financial markets, borrowers typically have better knowledge about their capabilities than do lenders (Myers \& Majluf, 1984). But due to moral hazard, borrowers cannot be expected to be entirely straightforward about their characteristics, since there are substantial rewards for exaggerating positive qualities. Financial intermediaries emerge as a solution to this problem, by signaling value to financial markets as a function of the size of the stake that intermediaries take in borrowers (Allen \& Santomero, 1997; Campbell \& Kracaw, 1980; Peng \& Wang, 2002). As a result, "information asymmetries may be a primary reason that [financial] intermediaries exist" (Leland \& Pyle, 1977: 383). Similarly, information asymmetries are pervasive in international trade, which is characterized by geographic and cultural separation between buyers and sellers (Peng \& Wang, 2002). International trade intermediaries, such as export trading companies, thus serve as a bridge connecting domestic producers and foreign buyers (Peng \& York, 2001). Specifically, trade intermediaries can conduct market research for prospective exporters, negotiate the deal on their behalf, and help enforce the contract (Ellis, 2003; Trabold, 2002).

Although financial and trade intermediation cases show excellent examples of value-adding mechanisms of traditional intermediaries, our entrepreneurship-as-intermediation perspective can be applied more broadly as long as the more general context of pervasive information asymmetries exists. We suggest that information asymmetries that require market-making intermediation would be more prevalent in industries that require complex sets of knowledge. In knowledge-intensive industries, it is likely that complex, tacit, and specialized knowledge would bring high levels of information asymmetries between knowledge sources and recipients (Graebner, Eisenhardt, \& Roundy, 2010). Thus, intermediaries with deeper knowledge about the specialized transaction processes under information asymmetries may be able to exploit this knowledge, while intermediaries with more general knowledge about the generic transaction processes may be less able to do so (Fiet, 2007). 
In sum, we define intermediation as any entrepreneurial roles in discovering or creating entrepreneurial opportunities by making markets between potential buyer and sellers in the value chain, and argue that intermediaries are especially likely to emerge in sectors whereby information asymmetries are considerable, such as in industries requiring complex knowledge. Extending this logic, in the next section we suggest that many entrepreneurs may be fruitfully conceptualized as intermediaries who discover or create entrepreneurial opportunities by making markets.

\section{ARE ENTREPRENEURS INTERMEDIARIES?}

The observation that entrepreneurs discover, create, and exploit opportunities has been well documented (Baker \& Nelson, 2005; Kirzner, 1997; Shane \& Venkataraman, 2000). What needs to be argued here is that these entrepreneurial actions can be interpreted as basically market-making intermediation activities in the value chain, particularly when information asymmetries are prevalent.

\section{Two Main Assumptions}

Our arguments hinge on two main assumptions. First, we draw on Austrian economics to assume an uncertain, disequilibrium world (Kirzner, 1997; Schumpeter, 1934; Shane \& Venkataraman, 2000). In an equilibrium, entrepreneurial opportunities either do not pre-exist to or can be exploited by all economic actors. However, in the real world, this is not likely to be the case, because information is imperfectly distributed both temporally and spatially (Casson, 2000; Evans \& Wurster, 1997). Thus, not all economic actors have the same amount and quality of information at the same time/location, thereby leading to entrepreneurial opportunities perceived by some (but not all) entrepreneurs (Brown, Davidsson, \& Wiklund, 2001; Foss et al., 2008).

A second assumption is that there are persistent market failures due to information asymmetries, bounded rationality, and opportunism (Williamson, 1985). While markets do not always 
fail, transaction costs cannot be reduced to zero, thus always leaving room for more innovative ways to lower transaction costs than status quo, an opportunity that entrepreneurs can discover or create.

\section{What Do Entrepreneurs Do?}

Considering information asymmetries and market failures, a short answer to the question, "What do entrepreneurs mainly do in industries requiring complex knowledge?" is that they make markets. Markets are interlocking economic relationships among a diverse set of buyers and sellers of goods and services (Spulber, 2009). A market-making view of entrepreneurs focuses attention on their intermediation role (Casson, 2000; Michael, 2007; Spulber, 1996, 1999, 2009).

As briefly discussed earlier, in distribution markets, intermediation between customers and suppliers is the primary economic activity of entrepreneurs. The emergence of the Internet is a case in point. New intermediaries (such as Amazon) emerge to displace some incumbent intermediaries and create new markets with a new set of distribution channels (Anderson \& Anderson, 2002). For example, in the insurance industry, the use of the Internet brought a 10 percent decrease in insurance prices (Brown \& Goolsbee, 2002).

In addition, the role played by intermediaries in financial markets such as venture capitalists is hardly disputed (Balboa \& Marti, 2007; Lim \& Cu, 2012; Wright, Robbie, \& Ennew, 1997). The expansion of venture capital is now a worldwide phenomenon (Ahlstrom, Bruton, \& Yeh, 2007; Wright, 2007). Venture capitalists not only cater to individual investors and pool risks for them, but also reduce transaction costs associated with bringing products to market by providing start-up firms with financial resources in a new way that alternative suppliers of capital (e.g., traditional financial intermediaries such as banks) were unable to do. While traditional financial intermediaries tend to require borrowing firms' tangible assets as security for loans, venture capitalists can provide start-ups with little tangible assets with equity financing by taking advantage of information and knowledge expertise on the focal businesses (Cressy, 2006; Lim \& Cu, 2012). Therefore, based on their superior 
information and knowledge to intermediate between individual investors and start-ups under information asymmetries, venture capitalists would tolerate more risks than traditional financial intermediaries.

Entrepreneurs in technology markets also connect suppliers and end users in new ways, resulting in the emergence of new markets. The rise of enterprise resource planning (ERP) software firms (e.g., SAP and Oracle) serves as another case in point. These firms use standard Windows-type applications from their suppliers, and then develop proprietary software to automate finance, manufacturing, and human resources for large corporations. From less than $\$ 1$ billion sales in 1990 , the new market they have created has been spectacular: It reached $\$ 84$ billion by 2008 .

Overall, it is reasonable to suggest that these intermediaries are entrepreneurial firms, and that they are, in essence, market makers who connect sellers and buyers. Specifically, the presence of asymmetric information between pairs of transaction parties (Assumption 1) creates an opportunity for intermediation. Further, the market failures of existing exchange institutions (Assumption 2) enable these entrepreneurs who can save transaction costs for both sides to carve out new market niches (Dean \& McMullen, 2007).

\section{Challenges to Overcome}

Strictly speaking, our entrepreneurship-as-intermediation perspective is not that new, if we revisit Schumpeter's (1934) classical insights that focused on entrepreneurs' role in "new combinations" and Cantillon (1959) and Kirzner's (1997) seminal work that equated entrepreneurship with arbitraging. What is surprising is that given so much research on intermediaries, especially on venture capitalists, an encompassing view of entrepreneurs as intermediaries has not emerged (Spulber, 1999, 2009).

In our view, there are two major challenges that this new perspective has to overcome. First, research focusing on venture capitalists concentrates on how they interact with narrowly defined "entrepreneurs" (i.e., start-ups) in order to help the latter succeed (which is, of course, important), 
instead of studying venture capitalists as entrepreneurs in their own right. This differentiated treatment reveals the field's focus on the producer role of entrepreneurial firms and its negligence of the merchant role of entrepreneurial firms (Hackett, 1992; Spulber, 2003). Our proposal that intermediaries such as venture capitalists can be labeled as entrepreneurs does not merely represent a change in semantics. Although we agree that venture capitalists and start-ups play different roles, to build a theory of entrepreneurship we must strive for a higher level of abstraction by focusing on their fundamental similarities. Various theories of the firm (Conner, 1991) do not burden themselves by differentiating one type of firms (e.g., manufacturing) from another type (e.g., venture capital firms), and it is only through such a high level of abstraction that theoretical progress can be made.

A second challenge may be the lack of an overarching conceptual framework within which to consider key research questions. A number of theoretical models, such as ecological, evolutionary, resource dependence, and transaction cost approaches, have been adopted in entrepreneurship research focusing on entrepreneurs that are not financial intermediaries (Aldrich, 1999: 42-74; Busenitz et al., 2003). On the other hand, finance researchers have developed a well-established theory of financial intermediaries (Allen \& Santomero, 1997; Lerner, 1995). Similarly, research on international trade intermediaries has increasingly focused on the market-making role of intermediaries thriving under conditions of information asymmetries internationally (Ellis, 2003; Peng \& York, 2001; Trabold, 2002). These streams of research on intermediation have been developing in parallel with traditional research on entrepreneurship, with relatively little cross-fertilization. Given the need for more rigorous conceptual development in entrepreneurship research, we posit that our proposed entrepreneurship-asintermediation perspective can help specify conditions under which entrepreneurs discover and create opportunities through intermediation. 


\section{A NEW RESEARCH AGENDA: PREDICTIONS, QUESTIONS, AND INTEGRATION}

While the entrepreneurship-as-intermediation perspective can be used to explain a large number of entrepreneurial activities, the ultimate test for the maturity of a scientific field is empirical predictions (Kuhn, 1970; Popper, 1972). Empirical predictions need to focus on fundamental questions. In this paper, we depart from and extend the two key questions on (1) why entrepreneurs arise and exist and (2) why some entrepreneurs outperform others in adding value and creating wealth. We identify the boundary conditions of our perspective using these two questions that have been regarded by numerous scholars as key building blocks for a theory of entrepreneurship (Amit et al., 1993: 815). While other research questions can be raised, we believe that they all relate in one way or the other to these two.

Another tendency in the entrepreneurship literature is to fortify its boundaries by highlighting its distinctiveness vis-à-vis its neighboring disciplines, in particular strategic management (Bruyat \& Julien, 2000: 173; Shane \& Venkataraman, 2000: 217). However, given that entrepreneurship is likely to be "one of the most complex in the social sciences," scholars will "have to borrow methods and tools from other disciplines and fields" (Bruyat \& Julien, 2000: 177-8), thus suggesting that theoretical integration-as opposed to theoretical isolation-is a must (Busenitz et al., 2003).

Toward that end, the proposed new research agenda centers on an eclectic integration of two influential schools of thought, TCE and RBV (Peng \& Wang, 2002). While other theories can also be invoked, this paper, as a first step toward advancing a parsimonious entrepreneur-as-intermediary view, invokes these two most relevant theories with a focus on the two key questions centered on the nature of entrepreneurship (Amit et al., 1993; Foss et al., 2008) (see Figure 1). Specifically, we argue (1) that the answer to the first question, "Why do entrepreneurs exist?" can converge with research on entrepreneurial opportunity discovery, and (2) that the answer to the second question, "Why do some entrepreneurs perform better than others in adding value and creating wealth?" can converge with the 
work on entrepreneurial opportunity creation in the process of entrepreneurs' uncertainty-bearings through their intermediation between potential buyers and sellers.

[Insert Figure 1 here]

\section{WHY DO ENTREPRENEURS AS INTERMEDIARIES EXIST?}

\section{Theoretical Background}

Since TCE starts with a key question, "Why do firms exist?" a natural extension of this perspective can help us understand why entrepreneurs exist. The theory posits that firms attempt to minimize transaction costs when making governance choices (Williamson, 1985). Show in Figure 2a, suppose (1) that the buyer is willing to pay a price, $\mathrm{P},(2)$ that the seller and the buyer encounter total transaction costs, $\mathrm{TC}_{1}$, and (3) that there is value creation from this transaction (Foss \& Foss, 2008):

$$
\mathrm{P}-\mathrm{TC}_{1}>0
$$

[Insert Figure 2 here]

Suppose that an entrepreneur is interested in getting involved in this transaction. The entrepreneur thus competes with direct transaction as an intermediary. For the seller and the buyer, instead of dealing directly with each other, they now transact with and through the entrepreneur, with a new set of transaction costs, $\mathrm{TC}_{2}$ (Figure $2 \mathrm{~b}$ ). In Figure $2 \mathrm{~b}, \mathrm{TC}_{2}$ is the sum of the transaction costs of the A side between the seller and the entrepreneur and the transaction costs of the B side between the buyer and the entrepreneur. It is apparent that the intermediated transaction through the entrepreneur will occur if and only if the entrepreneur lowers the first set of transaction costs:

$$
\mathrm{TC}_{2}<\mathrm{TC}_{1}
$$

As a result, to exist and succeed, entrepreneurs must lower the transaction costs relative to the other, direct trade mode; otherwise, there will be no rationale for their existence (Peng, Zhou, \& York, 
2006). According to Williamson (1985), transaction costs can be divided into two key constituent components: the ex ante search costs and the ex post monitoring/enforcement costs. It, thus, follows that entrepreneurs who can lower the combination of search and monitoring/enforcement costs by exploiting information asymmetries are more likely to be chosen by sellers and buyers, and, thus, to have a better chance of survival and prosperity (Peng \& Wang, 2002).

\section{Exploiting Information Asymmetries}

Search costs are the ex ante costs to overcome information asymmetries through the gathering and processing of relevant information (Cooper, Folta, \& Woo, 1995; Fiet, 2007). Buyers and sellers constantly search for the best deal to maximize the gains of transaction (Graebner et al., 2010). From the perspective of entrepreneurs, sellers are providers of resources with which entrepreneurs add value (Fiet \& Patel, 2008), while buyers are customers who purchase entrepreneurs' value-added outputs.

Search costs are particularly important when entrepreneurs discover and exploit pre-existing market opportunities. If markets are in equilibrium and if there are no information asymmetries, search costs will be equal for everybody, and, by extension, entrepreneurial profits are not likely to exist because nobody needs to lower search costs (Kirzner, 1997; Peng \& Wang, 2002). But such a condition does not hold in the real world: Instead of continuing to search, buyers may settle for a higher price, sellers may accept a lower offer, or they may quit searching at all (Graebner et al., 2010). As a result, entrepreneurs that can lower such search costs are likely to emerge (Zhang \& $\mathrm{Li}, 2010$ ).

However, not all industries, sectors, and geographic markets are in the same state of disequilibrium; some are more turbulent than others. Therefore, the higher the level of disequilibrium, the stronger the information asymmetries, and the more likely the emergence of certain entrepreneurs to profit from intermediation activities will be (Allen \& Santomero, 1997; Zhang \& Li, 2010). In other words, entrepreneurs thrive on chaos (Brown \& Eisenhardt, 1998). Since the extent of knowledge complexity would determine the degree of information asymmetries in an industry because knowledge 
sources and recipients are not likely to possess enough information about knowledge characteristics (Chang, Gong, \& Peng, 2012). Thus, buyers may not have the knowledge to be able to identify with whom they have to transact with at what prices. In a similar vein, sellers may be unable to identify which parties can successfully absorb and utilize their knowledge (Graebner et al., 2010). A high level of information asymmetries arising from knowledge complexity may be a basis of discovering and exploiting entrepreneurial opportunities through intermediation (Fiet, 2007). Therefore:

Proposition 1: The more complex knowledge is required in an industry, the more likely that entrepreneurs will discover and exploit for themselves opportunities arising from a high level of information asymmetries between potential buyers and sellers.

\section{Minimizing Monitoring/Enforcement Costs}

In addition to minimizing search costs, the entrepreneurship-as-intermediation perspective also needs to consider "the monitoring and enforcement side of the cost equation" (Peng \& Wang, 2002). This is because a high level of information asymmetries between potential buyers and sellers, per se, would not fully explain why entrepreneurs emerge as intermediaries rather than the potential buyers and sellers themselves exploiting opportunities by getting together.

Once market research is finished and contracts signed, the next thing that buyers and sellers are naturally concerned with is the monitoring of contractual obligations and enforcing contractual performance (Peng \& Wang, 2002; Phan, Butler, \& Lee, 1996; Pinkham \& Peng, 2013; Spulber, 1996). Financial intermediaries, for example, specialize in delegated monitoring (Diamond, 1984). Rather than directly lending to companies, investors place their funds with financial intermediaries that then screen and lend to companies. Therefore, investors can take advantage of financial intermediaries that are specialists in dealing with and monitoring certain kinds of start-ups in order to reduce information asymmetries. By monitoring many borrowers, financial intermediaries are able to achieve some economies of scale in monitoring. 
However, TCE indicates that for the same reason information asymmetries between buyers and sellers may prevent some transactions from taking place, information asymmetries between either party (buyers or sellers) on the one hand and entrepreneurs who stand in the middle as intermediaries on the other hand may also lead to transaction hazards-i.e., $\mathrm{TC}_{2}$ in Figure $2 \mathrm{~b}$ (Robbie, Wright, \& Chiplin, 1997). Specifically, entrepreneurs as intermediaries are agents for their clients on both sides (Norton, 1995). ${ }^{1}$ These agents may have incentive to behave in ways not always in the best interest of their principals, such as monopolizing communications between buyers and sellers, not paying attention to their principals' needs, or simply failing to perform as promised. Thus, buyers and sellers employing entrepreneurs as their intermediaries need to compare the monitoring/enforcement costs of going through the entrepreneurs vis-à-vis the monitoring/enforcement costs of going direct to market.

If these transaction costs are deemed too high, that is, $\mathrm{TC}_{2}>\mathrm{TC}_{1}$ in Formula 2 above, buyers and/or sellers may (1) vertically integrate either up-stream or down-stream; (2) switch agents by using a new set of entrepreneurs; and/or (3) quit transacting at all (Peng \& York, 2001). Therefore, entrepreneurs' chances of being selected and retained also depends on whether they can assure their transaction partners on both ends (A and B sides in Figure 2b). Specifically, entrepreneurs need to demonstrate that the potential agency costs will be less than the monitoring/enforcement costs these players would have incurred when engaging in direct transaction (Chintakananda, York, O’Neill, \& Peng, 2009; Foss \& Foss, 2008; Michael, 2007). For example, the fees charged by international trade intermediaries, which can be a proxy for the agency costs for both exporters (sellers) and importers (buyers) to absorb, cannot be too excessive. If the fees are too high, exporters and importers may choose to trade directly with each other (Peng \& York, 2001).

\footnotetext{
${ }^{1}$ In the case of venture capitalists, this assertion follows Norton (1995: 22) to view the venture capitalist as the agent for both the start-up entrepreneur and the investors.
} 
In sum, entrepreneurs as intermediaries have an incentive to minimize information asymmetries between themselves and their principals (buyers and sellers) on both the A side and the B side in Figure $2 \mathrm{~b}$ in order to discover and exploit value-adding opportunities. The chances of reducing information asymmetries between entrepreneurs and transaction parties would be higher when entrepreneurs possess prior experience in dealing with the focal knowledge that may be exploited through intermediation. Intermediaries' experience in complex knowledge may be able to reduce monitoring and enforcement costs because experienced intermediaries would capture the value that otherwise would be lost due to uncertainties perceived by buyers and sellers. Therefore:

Proposition 2: The more knowledgeable entrepreneurs are about an industry, the more likely they will discover and exploit opportunities to reduce information asymmetries between entrepreneurs and transaction parties (sellers and buyers)—specifically, between entrepreneurs and sellers (side A in Figure 2b) and between entrepreneurs and buyers (side B in Figure 2b).

Overall, entrepreneurs arise as intermediaries to discover opportunities and to take advantage of information asymmetries separating buyers and sellers due to knowledge complexities (Brown \& Eisenhardt, 1998). These entrepreneurs lower search and monitoring/enforcement costs of the transaction process by linking buyers and sellers together-in other words, making markets (Peng \& Wang, 2002; Spulber, 2009). But on the other hand, entrepreneurs live in a precarious world: While their very existence depends on how well they exploit information asymmetries, they could only take advantage of information asymmetries to a certain degree, because too much exploitation of these asymmetries that result in $\mathrm{TC}_{2}$ to exceed $\mathrm{TC}_{1}$, which may render themselves out of business (Ellis, 2003; Peng \& York, 2001). Moreover, while TCE helps us understand why entrepreneurs exist, it is relatively weak in explaining and predicting why some entrepreneurs are better able to create new market opportunities than others do. Next, we draw on the RBV to address this issue. 


\section{WHY ARE SOME ENTREPRENEURS BETTER AT CREATING ENTREPRENEURIAL OPPORTUNITIES?}

\section{Theoretical Background}

Extending from Austrian economics, our RBV rationale draws upon Penrose (1959). She argues that the heterogeneity of entrepreneurs' competitive advantage does not come from the resource availability in pre-existing markets but from the heterogeneity of their services from resources. This argument implies that different entrepreneurs commit to different entrepreneurial actions because they have different beliefs and knowledge sets about opportunity enactment process that create new markets through intermediation (Barney, 2001; Foss et al., 2008; Klein, 2008).

Similar to the Austrian economics perspective on the disequilibrium of opportunities (our Assumption 1), our resource-based logic argues for a disequilibrium of capabilities. It is precisely such differential in capabilities that leads to the success and failure of entrepreneurial firms under uncertain transaction environments with positive transaction costs (Foss \& Foss, 2008; Yamakawa, Peng, \& Deeds, 2008). Keeping this nature of entrepreneurs' competitive advantage in mind, this section discusses under what conditions entrepreneurs as intermediaries create and exploit opportunities.

\section{Competing on Knowledge Execution}

In order to present low search cost solutions portrayed in Proposition 1, searching for information is a central task for entrepreneurs (Cooper et al., 1995; Fiet, 2007). During the process, they often develop deep knowledge of the transaction process between existing and potential sets of buyers and sellers.

The best entrepreneurs are likely to have the best knowledge of the information asymmetries that make existing transactions inefficient (Dean \& McMullen, 2006). Such knowledge enables them to tap into what Burt (1997: 342) calls "non-redundant structural holes" in the transaction process, and to add value by "brokering the connection between others." For example, when encountering the same technological change (e.g., a patent), different entrepreneurs react differently, and people who have 
developed particular knowledge through education, experience, and network contacts are more likely than others to discover entrepreneurial opportunities (Cooper et al., 1995).

However, this knowledge leveraging mechanism is only the discovery part of entrepreneurial opportunities. In the case of emerging industries, by definition, there are not many knowledge opportunities that can be discovered through intermediation in the first place. Thus, entrepreneurs need to turn existing knowledge into new market opportunities (Yamakawa, Khavul, Peng, \& Deeds, 2013). For instance, technological knowledge and business ideas for launching and managing social media services such as YouTube neither come from the vacuum, nor are they entirely novel. However, the entrepreneurial enactment of YouTube's founders has created new market spaces that online users themselves can produce and distribute to other online users. In this sense, entrepreneurs' opportunity creation may be based on subjective judgments and actions that differ by individuals, and entrepreneurial strategies often emerge from such path dependencies (Fiet, 2007; Foss et al., 2008).

When it comes to opportunity creation, the best-performing entrepreneurs tend to excel at aggressively executing knowledge that they can leverage through their social ties into actions (Ellis, 2003; Fiet, 2007; Wood \& McKinley, 2010). In this process, some entrepreneurs are likely to seize opportunities with little planning, and execute their vision without proving its worth (Bhide, 1994; Honig \& Karlsson, 2004). Many entrepreneurial visions and concepts, although informed by entrepreneurs' prior knowledge, are difficult to prove. But, once proven, they are easy to imitate. Therefore, entrepreneurs are often tempted to aggressively and quickly extract rents from such knowledge based on sketchy plans and inconclusive data (Delmar \& Shane, 2003).

Fueled by an entrepreneurial orientation (Dess, Pinkham, \& Yang, 2011; Lumpkin \& Dess, 1996; Tang \& Tang, 2012), entrepreneurs are often interested in seeking first-mover advantages, and the best ones often possess rare capabilities in coordinating resources that enable them to capitalize on these opportunities (Klein, 2008). These capabilities are often uncodifiable, intangible, and difficult to 
teach and imitate (Fiet, 2007). For example, in the absence of a proven business model, Amazon not only discovered that an online bookstore could overcome information asymmetries between book publishers and buyers, but also aggressively leveraged such knowledge by rapidly building the world's largest book warehouses, which ironically are "brick-and-mortar."

On the other hand, it is important to caution against over-aggressiveness in leveraging such knowledge, in light of entrepreneurs' well-documented tendency to be overconfident (Michael, 2007). For example, more than $90 \%$ of the venture capitalists surveyed by Zacharakis and Shepherd (2001) and Hayward, Shepherd, and Griffin (2006) exhibit significant overconfidence. The best entrepreneurs embrace uncertainties, yet protect themselves against excessive downside risk. For example, some venture capitalists employ a real options reasoning by using well-known milestones or "rounds" of financing to stage and sequence their commitment to uncertain projects (McGrath, 1999).

Entrepreneurs failing to do so may end up suffering huge losses.

But overall, it appears that both having critical knowledge and leveraging such knowledge (up to a certain extent) go hand-in-hand in leading to good entrepreneurial performance in terms of growth in new markets such as emerging industries (Yamakawa et al., 2008, 2013). Thus:

Proposition 3: The more aggressive entrepreneurs turn their existing knowledge into actions, the more likely those entrepreneurs will be able to intermediate between potential buyers and sellers in order to create entrepreneurial opportunities and generate more wealth.

\section{Competing on Signaling Capabilities}

In emerging industries, where information asymmetries are unavoidable, sometimes entrepreneurs themselves often create information asymmetries between potential buyers and sellers to increase the chances of creating new markets and exploit these new market opportunities by themselves. However, entrepreneurs face a dilemma: This is because the new information asymmetries introduced in a principal-agent relationship between sellers and entrepreneurs on the one hand (side A in Figure 2b) 
and between buyers and entrepreneurs (side B in Figure 2b) on the other hand may deter potential buyers and sellers from entering transaction relationships with entrepreneurs. However, entrepreneurs' very existence depends on the information asymmetries between potential buyers and sellers. Reducing such asymmetries is not only costly, but may also seriously undermine their business (Ellis, 2003). The challenge for entrepreneurs, therefore, is how to assure their clients on both ends that the monitoring/enforcement costs of using their services are lower than the monitoring/enforcement costs that buyers and sellers would have incurred should they trade directly $-\mathrm{TC}_{2}<\mathrm{TC}_{1}$ specified in Formula 2 above (Peng \& York, 2001; Spulber, 2003).

A key strategy for entrepreneurs as intermediaries is to use observable opportunity enactments (Wood \& McKinley, 2010) to signal to principals that they are credible (Spence, 1973). Particularly in emerging industries, entrepreneurs can share some portions of uncertainties with their sellers (resource providers) through their enacted commitments and credible signaling based on those commitments (Fiet \& Patel, 2008). Signaling through enactment processes in the absence of established markets can provide credible commitments to potential buyers and sellers. Therefore, we suggest that entrepreneurs compete on their signaling capabilities, and that the best-performing entrepreneurs are likely to be those with the best signaling capabilities (Campbell \& Kracaw, 1980). This can be accomplished through behavioral and/or outcome measures.

Wood and McKinley (2010) highlight two primary behavioral measures. The first behavioral signal is reputation. Often earned through years of hard work, reputation is difficult to acquire in a short time and even more challenging to imitate (Podolny, 1994). Reputation thus serves as a powerful behavioral measure to signal to principals about entrepreneurs' credibility as intermediaries (Chemmanur \& Fulghieri, 1994). Also, reputable entrepreneurs such as venture capitalists often take equity in borrowers in order to signal to investors that venture capitalists have no incentive to misrepresent their information. If smaller, entrepreneurial firms do not have a strong reputation, it is 
possible for them to team up with large firms as strategic alliances in order to enhance the legitimacy of the smaller firms (Zimmerman \& Zeitz, 2002). ${ }^{2}$

Another behavioral signal related to reputation is entrepreneurs' social ties (Ellis, 2003; Hsu, 2006; Shane \& Stuart, 2002). Social ties would enable "the flow of information from entrepreneurs to stakeholders" including potential buyers and sellers (Wood \& McKinley, 2010: 73). This information flow not only helps persuade stakeholders of the feasibility of an opportunity, but also supports the entrepreneur's confidence in opportunity enactment.

Outcome measures include contracts whose renewal is contingent upon satisfactory performance. These contracts, however, still entail substantial monitoring and enforcement costs. The most extreme form of outcome control is to require that entrepreneurs assume ownership of the goods (Hackett, 1992). Taking title to the goods by entrepreneurs solves a major agency problem inherent in the principal-agent relationship by completely aligning the interests of both parties. In export trade, exporters no longer need to incur monitoring/enforcement costs as long as trading companies take title to the goods, thus transforming the entrepreneurs from agents to principals (Peng \& York 2001).

However, not all entrepreneurs have the same signaling capabilities (Peng \& Wang, 2002). A lot of them simply do not have a good reputation upon which they can leverage existing social ties to support the enactment processes (Ellis, 2003). In addition, many of them are unable to meet the stringent requirements imposed by principals (e.g., taking title to the goods in export trade) due to a lack of resources (Peng \& York, 2001). Thus, the capabilities to differentiate signals sent to principals on how monitoring/enforcement costs are reduced may differentiate entrepreneurs who successfully create new market opportunities from those who fail in opportunity enactment processes. Thus:

\footnotetext{
${ }^{2}$ It is difficult for entrepreneurial firms to manage alliances with larger firms and not having the value created by these alliances appropriated by the large firms (Deeds \& Hill, 1998). Therefore, small firms that are able to succeed in these alliances may possess unusually strong alliance management capabilities that may give rise to their performance.
} 
Proposition 4: The better the capabilities of entrepreneurs to signal to their principals about their credibility through behavioral and/or outcome means, the better entrepreneurs will be able to intermediate between potential buyers and sellers in order to create new market opportunities.

Overall, the RBV suggests that entrepreneurial growth in emerging industries is likely to be driven by the differences in entrepreneurs' capabilities to execute knowledge in the process of opportunity enactment and in signaling capabilities through behavioral and/or outcome means.

\section{DISCUSSION}

\section{Contributions}

Focusing on key questions in entrepreneurship research, three contributions emerge. First, this paper sketches the contours of a theory of entrepreneurship focusing on the nature of entrepreneurship as intermediation under information asymmetries. It advances a parsimonious and testable research agenda. The notion of intermediation as an essential component of entrepreneurship covers, but is certainly not limited to, intermediary firms such as venture capitalists (Spulber, 1999: 349). The hallmark of this perspective is its broad coverage of entrepreneurial activities as long as these activities add value by making markets under information asymmetries. In particular, it resonates with Shane and Venkataraman's (2000: 218) focus on the sources of opportunities (information asymmetries and market failures), the processes of discovery, evaluation, and exploitation of opportunities (minimizing search and monitoring/enforcement costs and competing on knowledge and signaling capabilities), and the set of entrepreneurial individuals and organizations that excel at these tasks. When knowledge required in an industry is complex to transact and when an industry is emerging, a high level of information asymmetries would lead entrepreneurs who discover and create opportunities to exploit those opportunities by intermediation. Overall, we have gone beyond Cantillon and Kirzner's notion of arbitrage and highlighted both the importance of discovering opportunities and the importance of 
creating opportunities in the context of coordinating resources and capabilities within a firm. To clarify, we do not claim all firms that intermediate between buyers and sellers under information asymmetries are entrepreneurs who discover and create entrepreneurial opportunities. In the same spirit, we do not claim all entrepreneurs should discover and create entrepreneurial opportunities via intermediation either. Rather, we argue that in industries where required knowledge sets are complex and thus lead to higher information asymmetries, entrepreneurs who are willing and able to bear uncertainties are highly likely to exploit entrepreneurial opportunities via making markets.

A second contribution is our integration of two influential schools of thought, which share an important premise in the literature that entrepreneurs add value by bearing uncertainties that other economic agents would be neither willing nor able to bear. Although some scholars such as Bruyat and Julien (2000) and Shane and Venkataraman (2000) argue that entrepreneurship research needs to be sufficiently distinct vis-à-vis other fields, the same individuals usually also call for harvesting the best available insights in existing social science research. In such a spirit, this article draws from the insights of TCE and RBV. These two well-established theories are often pitted against each other but are actually complementary (Peng, Hill, \& Wang, 2000; Yang, Ho, \& Chang, 2012). The relationship between them seems to be that while TCE "informs the generic decision [of governance choices]," the RBV "brings in particulars" (Williamson, 1999: 1097, original italics). In this article, the two TCE propositions answer the generic question of why entrepreneurs arise and exist, while the two RBV propositions provide the particulars on how some entrepreneurs outperform others in wealth creation. In other words, the two TCE propositions seem to be "feeding into" the two RBV ones (Williamson, 1999: 1098), thus leading to a theoretical integration (Peng \& Wang, 2002).

Finally, we link two representative theories of the firm (TCE and RBV) to the two recent theoretical streams in entrepreneurship research (the opportunity discovery approach and the opportunity creation approach). Our core arguments are twofold. (1) The entrepreneurial governance 
question raised by TCE is more relevant to explain that the information asymmetries condition is necessary for entrepreneurs to intermediate, discover, and exploit opportunities in existing markets. (2) The heterogeneity question raised by RBV is more relevant to explain how some entrepreneurs are better able to create new opportunities and generate new wealth than others.

\section{Practical Implications}

For current and would-be entrepreneurs, our perspective suggests how entrepreneurs may find competitive advantage under conditions of information asymmetries. Specifically, entrepreneurs are viewed as a bridge connecting their customers and suppliers. These market makers succeed by building the most effective bridges - that is, by continuously developing innovative transactions linking different sets of buyers and sellers (Burt, 1997; Casson, 2000; Li, Young, \& Tang, 2012; Spulber, 2009). Furthermore, our argument can extend Burt's intermediation logic that assumes economic players in different domains in the value chain are "so focused on their own activities," thus they have "little time to attend to the activities of others" and tend to "circulate in different flows of information" (Burt, 1997: 342). Our view implicitly posits that intermediaries (such as venture capitalists) are likely to "internalize" entrepreneurial opportunities by becoming owners and/or founders of start-ups if they perceive they can better discover and/or create opportunities via internalization instead of playing boundary-spanning brokering roles (Kaplan \& Stromberg, 2003; Klein, 1999).

To be successful, entrepreneurs must acquire, develop, and deploy resources that can lower their principals' search and monitoring/enforcement costs, thus creating value and generating wealth. The wealth-generating opportunities through intermediation would be more frequently discovered and created in emerging industries rather than established industries. This point provides an important implication that intermediation can help entrepreneurs to create wealth through systematic and constrained search (Fiet, 2007). Moreover, in order for entrepreneurs to create wealth through intermediation, they have to rely on their existing experience, proactive execution, and signaling. 
We also argue that entrepreneurship can be a proactive activity. A lot of entrepreneurs may lack significant tangible resources. However, they often compensate for such a lack of tangible resources by being proactive (Mishina, Pollock, \& Porac, 2004; Peng, 2001). In other words, instead of waiting for opportunities to present themselves, resource-poor but enthusiastic entrepreneurs can and need to constantly search for opportunities (Katila \& Shane, 2005). Intermediaries, such as venture capitalists and international trade intermediaries, are well known for their proactive search of deals (Peng \& York, 2001; Peng et al., 2006). Extending more broadly to other entrepreneurs, such proactive activity represents the spirit of entrepreneurship that needs to be fostered.

\section{Future Research Directions}

This paper points out at least four directions for future research. First, there is substantial room for conceptual clarification. How entrepreneurs can exploit information asymmetries yet containing their downside risk remains an intriguing paradox for additional work, perhaps in connection with real options theory (McGrath, 1999) and complexity theory (Brown \& Eisenhardt, 1998). For instance, we do not know much about when and how entrepreneurs as intermediaries can take advantage of information asymmetries and increase the chances of creating new markets and exploit these entrepreneurial opportunities by themselves.

Complexity theory may shed a light on the field to identify the conditions under which entrepreneurs deliberately create information asymmetries to later resolve those asymmetries for their potential buyers and sellers (McKelvey, 2004). For example, Lichtenstien, Carter, Dooley, and Gartner (2007) argue that adaptive tension may lead to the creation of new firms. In the process, interdependence between the firms may become the cause of maladaptation, which would be the source of new firm creation. This new firm creation is a recursive process in that new firm creation would lead to more new firm creation. In other words, new firm creation may create new information asymmetries that give room for more new firm creation. 
In a similar vein, the entrepreneurship literature does not have much prior knowledge on the key entrepreneurial efforts by which some entrepreneurs in an industry can better create marketmaking opportunities when knowledge characteristics of the industry have become more complex. Real options theory may be able to help scholars to identify the types of real option investments in the context of intermediation. For example, due to the risk involved in the initial intermediation effort, potentially the first endeavor may prove to be a failure (McGrath, 1999). However, when the endeavors are considered as a bundle, while there may be a lot of failures those successful ones can be of great influence in the future businesses (Lee, Peng, \& Barney, 2007). In addition, once intermediation endeavor is made, the risk associated with this endeavor can also be mitigated by new entries with the similar function that reduces the risk of the business (Lee, Bach, \& Baik, 2011).

Second, although some existing empirical research can be re-interpreted to support our perspective, the propositions have not been tested in a single study, thus leaving room for more rigorous empirical tests. Further development of measures on key constructs such as knowledge complexity would be necessary to enhance the testability of the propositions. In fact, it would not be an easy task to empirically test the complexity of required knowledge across industries (Yamakawa et al., 2013). Previous empirical studies on technology-intensive industries have traditionally used patentbased measurement of knowledge complexity by comparing technological similarity between industries (Carayannopoulos \& Auster, 2010; Sorenson, Rivkin, \& Fleming, 2006). However, there would be various industries, other than technology-intensive industries, that provide entrepreneurs with intermediation opportunities stemming from complex knowledge required in the value chain.

For example, VCs can be considered as capital suppliers to entrepreneurial firms. The rise of VCs is due to the lack of potential capital supply from traditional banks. The reason is that traditional banks do not have expertise on involving in management of firms (especially new firms), which is essential when new entrepreneurial firms are in a high-tech industry. Thus, when the value of new 
entrepreneurial firms is mainly based on knowledge assets that are hard to value, the banks tend to decline the loans. In addition, due to information asymmetries, risky businesses are less likely to be welcomed by banks given that failure rate is high (Lee \& Yamakawa, 2012). For this reason, banks are reluctant to give loans to entrepreneurial firms especially in high-tech industry.

When interest rates rise entrepreneurs who borrow from banks tend to take more risks, making the project even less likely to be successful (Meza \& Webb, 1999). This is why banks set a ceiling on the rate of interest they charge, which is called credit rationing (Stiglitz \& Weiss, 1981). When banks charge an exceptionally high interest rate, it is more likely that entrepreneurs would engage in riskier projects that are less likely to be successful. Therefore, when it comes to high-tech industry, there would be higher information asymmetry between financial institutions and entrepreneurs. As a result, the role of traditional banks are limited and the emergence of VCs is to be seen. This is why many new biotech ventures seek VC funds while firms in traditional industries such as Wal-Mart tend to start their business with no VC funding (Bhide, 2000).

An alternative way to compare knowledge complexity between industries would be a comparison of industry relatedness in terms of required production factors. A recent study, for example, used an industry level value-added dataset constructed from the U.S. Census of Manufactures and measured the four-digit SIC industry relatedness by required economic resources to produce in each manufacturing industry (Bryce \& Winter, 2009). Future empirical studies can draw useful implications from such cross-industry data to classify certain industries, whose outputs heavily rely on production inputs that are complex. In those industries, entrepreneurs may enjoy better opportunities to intermediate between potential buyers and sellers to take advantage of information asymmetries stemming from complex knowledge requirement within industries.

Third, in terms of future empirical studies, while venture capitalists will continue to command research attention, we would like to encourage more research efforts on other types of entrepreneurial 
firms with a focus on their intermediation efforts. It would be fruitful to examine the opportunities that are discovered and created by entrepreneurs working as intermediaries. The literature suggests that there are at least four types of entrepreneurial intermediaries serving start-ups in order to access information and networks necessary for innovation: (1) technology service firms, (2) accounting and financial service firms, (3) law firms, and (4) talent search firms (Zhang \& Li, 2010). For example, entrepreneurship researchers know that law firms not only offer general business advice and legal guidance, but also help start-ups structure deals (Zhang \& Li, 2010). However, we do not know under what circumstances some law firms can better intermediate entrepreneurial opportunities between individual investors and start-ups than other service intermediaries such as accounting firms.

Finally, in our drive to present a parsimonious framework, we have concentrated on the economic aspects of the entrepreneurial process, and have not paid adequate attention to the social aspects (Aldrich, 1999) and institutional constraints that may also be critical building blocks for a theory of entrepreneurship (Lee et al., 2007; Lee, Yamakawa, Peng, \& Barney, 2011). Although we acknowledge that entrepreneurial competitive advantage under information asymmetries would be specific in time, space, and context, we have not explicitly identified social and institutional boundary conditions. Future research may need to build a more comprehensive model incorporating social and institutional factors that may bring us even closer to a general theory of entrepreneurship that the field can eventually claim to be its own.

However, we still do not know whether institutional differences between countries lead to significant differences in the extent of information asymmetries with the same industry. For instance, it would be worthwhile to explore whether entrepreneurs in countries having entrepreneur-friendly bankruptcy laws will have stronger institutional incentives to bear uncertainties via intermediation than entrepreneurs in some other countries (Peng, Yamakawa, \& Lee, 2010). 
Furthermore, entrepreneurs' propensity to bear uncertainties would be not only influenced by individual characteristics, but also by social dimensions such as national culture (Licht \& Siegel, 2006). In that sense, national cultural values may affect entrepreneur's overall propensity in a society to invest in building social capital necessary for future intermediation between otherwise disconnected economic actors (Li et al., 2012; Licht \& Siegel, 2006). It would be important that future research explain why entrepreneurs in some countries are willing to bear higher uncertainties to become marketmakers than entrepreneurs in other countries due to the differences in national cultural values.

\section{CONCLUSION}

What is the nature of entrepreneurship? If we can use only one word to describe the nature of entrepreneurship, it is intermediation. Striving for theoretical integration, this paper, in essence, can be viewed as an effort to intermediate among several strands of the literature. As the economy becomes more entrepreneurial, it is only natural that our research takes on an entrepreneurial character by profiting from traditional information asymmetries separating different pockets of the literature and by adding value with theoretical integration and extension.

\section{REFERENCES}

Ahlstrom, D., Bruton, G., \& Yeh, K. 2007. Venture capital in China: past, present, and future. Asia Pacific Journal of Management, 24: 247-268.

Akerlof, G. 1970. The market for lemons: quality uncertainty and the market mechanism. Quarterly Journal of Economics, 84: 488-500.

Aldrich, H. 1999. Organizations evolving. Thousand Oaks, CA: Sage.

Allen, F., \& Santomero, A. 1997. The theory of financial intermediation. Journal of Banking and Finance, 21: 1461-85.

Amit, R., Glosten, L., \& Muller, E. 1993. Challenges to theory development in entrepreneurship research. Journal of Management Studies, 30: 815-834. 
Anderson, P., \& Anderson, E. 2002. The new e-commerce intermediaries. MIT Sloan Management Review, 43(4): 53-62.

Baker, T., \& Nelson, R. 2005. Creating something from nothing: resource construction through entrepreneurial bricolage. Administrative Science Quarterly, 50: 329-366.

Balboa, M., \& Marti, J. 2007. Factors that determine the reputation of private equity managers in developing markets. Journal of Business Venturing, 22: 453-480.

Barney, J. B. 2001. Resource-based theories of competitive advantage: A ten-year retrospective on the resourcebased view. Journal of Management, 27: 625-641.

Bhide, A. 1994. How entrepreneurs craft strategies that work. Harvard Business Review, 72(2): 150-161.

Bhide, A. 2000. The origins and evolution of new business. New York: Oxford University Press.

Brandenburger, A., \& Stuart, H. 1996. Value-based business strategy. Journal of Economics and Management Strategy, 5: 5-24.

Brown, J., \& Goolsbee, A. 2002. Does the Internet make markets more competitive? evidence from the life insurance industry. Journal of Political Economy, 110: 481-507.

Brown, S., \& Eisenhardt, K. 1998. Competing on the edge. Harvard Business School Press: Boston, MA.

Brown, T., Davidsson, P., \& Wiklund, J. 2001. An operationalization of Stevenson's conceptualization of entrepreneurship as opportunity-based firm behavior. Strategic Management Journal, 22: 953-968.

Bruyat, C., \& Julien, P. 2000. Defining the field of research in entrepreneurship. Journal of Business Venturing, 16: $165-80$.

Bryce, D., \& Winter, S. 2009. A general interindustry relatedness index. Management Science, 55: 1570-1585.

Burt, R. 1997. The contingent value of social capital. Administrative Science Quarterly, 42: 339-365.

Busenitz, L., West, P., Shepherd, D., Nelson, T., Chandler, G., \& Zacharakis, A. 2003. Entrepreneurship research in emergence: past trends and future directions. Journal of Management, 29: 285-308.

Campbell, T., \& Kracaw, W. 1980. Information production, marketing signaling, and the theory of financial intermediation. Journal of Finance, 35: 863-882.

Cantillon, R. 1959. Essai sur la nature du commerce en general.[Essay on the nature of trade in general]. translated by Higgs, H. London: Frank Cass and Co.

Carayannopoulos, S., \& Auster, E. R. 2010. External knowledge sourcing in biotechnology through acquisition versus alliance: A KBV approach. Research Policy, 39: 254-267.

Casson, M. 2000. An entrepreneurial theory of the firm. In Enterprise and leadership, Casson, M. (eds). Cheltenham, UK: Edward Elgar.

Chang, Y., Gong, Y., \& Peng, M. W. 2012. Expatriate knowledge transfer, subsidiary absorptive capacity, and subsidiary performance. Academy of Management Journal, 55: 927-948. 
Chemmanur, T., \& Fulghieri, F. 1994. Investment bank reputation, information production, and financial intermediation. Journal of Finance, 49: 57-79.

Chintakananda, A., York, A., O’Neill, H., \& Peng, M. W. 2009. Structuring dyadic relationships between export producers and intermediaries. European Journal of International Management, 3: 302-327.

Conner, K. 1991. A historical comparison of resource-based theory and five schools of thought within industrial organization economics. Journal of Management, 17: 121-154.

Cooper, A., Folta, T., \& Woo, C. 1995. Entrepreneurial information search. Journal of Business Venturing, 10: 107-120.

Cressy, R. 2006. Venture capital. In Casson, M, Yeung, B., Basu, A., \& Wadeson, N. (eds), Oxford Handbook of Entrepreneurship. Oxford, UK: Oxford University Press.

Dean, T., \& McMullen, J. 2007. Toward a theory of sustainable entrepreneurship: reducing environmental degradation through entrepreneurial action. Journal of Business Venturing, 22: 50-76.

Deeds, D., \& Hill, C. 1998. An examination of opportunistic action within research alliances. Journal of Business Venturing, 14: 141-163.

Delmar, F., \& Shane, S. 2003. Does business planning facilitate the development of new ventures? Strategic Management Journal, 24: 1165-1185.

Dess, G. G., Pinkham, B. C., \& Yang, H. 2011. Entrepreneurial orientation: Assessing the construct's validity and addressing some of its implications for research in the areas of family business and organizational learning. Entrepreneurship Theory and Practice, September: 1077-1090.

Diamond, D. 1984. Financial Intermediation and Delegated Monitoring. Review of Economic Studies 51, 393 414.

Eckhardt, J. T., \& Shane, S. A. 2003. Opportunities and entrepreneurship. Journal of Management, 29: 333-349.

Ellis, P. D. 2003. Social structure and intermediation: market-making strategies in international exchange. Journal of Management Studies, 40; 1683-1708.

Evans, P., \& Wurster T. 1997. Strategy and the new economics of information. Harvard Business Review, 75(5): 71-82.

Fiet, J. O. 2007. A prescriptive analysis of search and discovery. Journal of Management Studies, 44: 592-611.

Fiet, J. O., \& Patel, P. C. 2008. Forgiving business models for new ventures. Entrepreneurship Theory and Practice, 32: 749-761.

Foss, K., \& Foss, N. 2008. Understanding opportunity discovery and sustainable advantage: the role of transaction costs and property rights. Strategic Entrepreneurship Journal, 2: 191-207.

Foss, N. J., Klein, P. G., Kor, Y. Y., \& Mahoney, J. T. 2008. Entrepreneurship, subjectivism, and the resourcebased view: toward a new synthesis. Strategic Entrepreneurship Journal, 2: 73-94. 
Graebner, M. E., Eisenhardt, K. M., \& Roundy, P. T. 2010. Success and failure in technology acquisitions: lessons for buyers and sellers. Academy of Management Perspectives, 24: 73-92.

Hackett, S. 1992. A comparative analysis of merchant and broker intermediation. Journal of Economic Behavior and Organization, 18: 299-315.

Hayward, M., Shepherd, D., \& Griffin, D. 2006. A hubris theory of entrepreneurship. Management Science, 52 : 160-172.

Honig, B., \& Karlsson, T. 2004. Institutional forces and the written business plan. Journal of Management, 30 : $29-48$.

Hsu, D. 2006. Venture capitalists and cooperative venture start-up in commercialization strategy. Management Science, 52: 204-219.

Kaplan, S. N., \& Stromberg, P. 2003. Financial contracting theory meets the real world: An empirical analysis of venture capital contracts. Review of Economic Studies, 70: 281-315.

Katila, R., \& Shane, S. 2005. When does lack of resources make new firms innovative? Academy of Management Journal, 48: 814-829.

Katz, J., \& Gartner, W. 1988. Properties of emerging organizations. Academy of Management Review, 13: 429441.

Kirzner, I. 1973. Competition and Entrepreneurship. University of Chicago Press: Chicago, IL.

Kirzner, I. 1997. Entrepreneurial discovery and the competitive market process: an Austrian approach. Journal of Economic Literature, 35(1): 60-85.

Klein, P. 1999. Entrepreneurship and corporate governance. Quarterly Journal of Austrian Economics, 2: 19-42.

Klein, P. 2008. Opportunity discovery, entrepreneurial action, and economic organization. Strategic Entrepreneurship Journal, 2(3): 175-190.

Kuhn, T. 1970. The Structure of Scientific Revolutions, $2^{\text {nd }}$ ed. University of Chicago Press: Chicago, IL.

Lee, S.-H., Bach, S., \& Baik, Y. 2011. The impact of new IPO on the values of directly competing incumbent. Strategic Entrepreneurship Journal, 5: 158-177

Lee, S.-H., Peng, M. W., \& Barney, J. B. 2007. Bankruptcy law and entrepreneurship development: a real options perspective. Academy of Management Review, 32: 257-272.

Lee, S.-H., \& Yamakawa, Y. 2012. Forgiving features for failed entrepreneurs vs. cost of financing in bankruptcies. Management International Review, 52: 49-79

Lee, S.-H., Yamakawa, Y., Peng, M. W., \& Barney, J. B. 2011. How do bankruptcy laws affect entrepreneurship development around the world? Journal of Business Venturing, 28: 505-520.

Leland, H., \& Pyle, D. 1977. Information asymmetries, financial structure, and financial intermediation. Journal of Finance, 32: 371-387.

Lerner, J. 1995. Venture capitalists and the oversight of private firms. Journal of Finance, 50: 301-318. 
Li, J., Young, M. N., \& Tang, G. 2012. The development of entrepreneurship in Chinese communities: An organizational symbiosis perspective. Asia Pacific Journal of Management, 29: 367-385.

Licht, A. N., \& Siegel, J. I. 2006. The social dimensions of entrepreneurship. In Casson, M, Yeung, B., Basu, A., \& Wadeson, N. (eds.), Oxford handbook of entrepreneurship. Oxford, UK: Oxford University Press.

Lichtenstein, B., Carter, N., Dooley, K., \& Gartner, W. 2007. Complexity dynamics of nascent entrepreneurship. Journal of Business Venturing, 22: 236-261.

Lim, K., \& Cu, B. 2012. The effects of social networks and contractual characteristics on the relationship between venture capitalists and entrepreneurs. Asia Pacific Journal of Management, 29: 573-596.

Lumpkin, G., \& Dess, G. G. 1996. Clarifying the entrepreneurial orientation construct and linking it to performance. Academy of Management Review, 21: 135-172.

McGrath, R. 1999. Falling forward: real options reasoning and entrepreneurial failure. Academy of Management Review, 24: 13-30.

McKelvey, B. 2004. Toward a complexity science of entrepreneurship. Journal of Business Venturing, 19: 313341.

Meza, D., \& Webb, D. 1999. Wealth, enterprise, and credit policy. Economic Journal, 109: 153-163.

Michael, S. C. 2007. Transaction cost entrepreneurship. Journal of Business Venturing, 22: 412-426.

Mishina, Y., Pollock, T., \& Porac J. 2004. Are more resources always better for growth? Resource stickiness in market and product expansion. Strategic Management Journal, 25: 1179-1197.

Myers, S., \& Majluf, N. 1984. Corporate financing and investment decisions when firms have information that investors do not have. Journal of Financial Economics, 13: 187-221.

Norton, E. 1995. Venture capital as an alternative means to allocate capital: an agency theoretic view. Entrepreneurship Theory and Practice, 20: 19-29.

Peng, M. W. 2001. How entrepreneurs create wealth in transition economies. Academy of Management Executive, 15(1): 95-108.

Peng, M. W., Hill, C., \& Wang, D. 2000. Schumpeterian dynamics versus Williamsonian considerations: a test of export intermediary performance. Journal of Management Studies, 37(2): 167-184.

Peng, M. W., \& Wang, H. 2002. An intermediation-based view of entrepreneurship. In Amit, R., Lucier, C. E., Hitt, M. A., \& Nixon, R. D. (eds.), Creating value: Winners in the new business environment. Oxford, UK: Blackwell.

Peng, M. W., Yamakawa, Y., \& Lee, S.-H. 2010. Bankruptcy laws and entrepreneur-friendliness. Entrepreneurship Theory and Practice, 34(3): 517-530.

Peng, M. W., \& York, A. S. 2001. Behind intermediary performance in export trade: transactions, agents, and resources. Journal of International Business Studies, 32(2): 327-346. 
Peng, M. W., Zhou, Y., \& York, A. S. 2006. Behind make or buy decisions in export strategy: a replication and extension of Trabold. Journal of World Business, 41(3): 289-300.

Penrose, E. T. 1959. The Theory of the Growth of the Firm. John Wiley: Cambridge, UK.

Phan, P., Butler, J., \& Lee, S. 1996. Crossing mother: Entrepreneur-franchisees' attempts to reduce franchisor influence. Journal of Business Venturing, 11: 379-402.

Pinkham, B. C., \& Peng, M. W. 2013. Arbitration and cross-border transaction costs. Working paper, Texas Christian University and University of Texas at Dallas.

Podolny, J. 1994. Market uncertainty and the social character of economic exchange. Administrative Science Quarterly, 39: 458-483.

Popper, K. 1972. Objective knowledge: An evolutionary approach. Oxford, UK: Oxford University Press.

Robbie, K., Wright, M., \& Chiplin, B. 1997. The monitoring of venture capital firms. Entrepreneurship Theory and Practice, 21(4): 9-28.

Sarasvathy, S. 2001. Causation and effectuation: toward a theoretical shift from economic inevitability to entrepreneurial contingency. Academy of Management Review, 26: 243-263.

Sarasvathy, S. 2004. The questions we ask and the questions we care about: reformulating some problems in entrepreneurship research. Journal of Business Venturing, 19: 707-717.

Schumpeter, J., 1934. The theory of economic development. Cambridge, MA: Harvard University Press.

Shane, S. 2000. Prior knowledge and the discovery of entrepreneurial opportunities. Organization Science, 11: 448-469.

Shane, S., \& Stuart, T. 2002. Organizational endowments and the performance of university start-ups. Management Science, 48: 154-170.

Shane, S., \& Venkatraman, S. 2000. The promise of entrepreneurship as a field of research. Academy of Management Review, 25: 217-226.

Sorenson, O., Rivkin, J. W., \& Fleming, L. 2006. Complexity, networks and knowledge flow. Research Policy, 35: 994-1017.

Spence, A. M. 1973. Market signaling. Cambridge, MA: Harvard University Press.

Spulber, D. F. 1996. Market microstructure and intermediation. Journal of Economic Perspectives, 10: 135-152.

Spulber, D. F. 1999. Market microstructure: Intermediaries and the theory of the firm. New York: Cambridge University Press.

Spulber, D. F. 2003. The intermediation theory of the firm: integrating economic and management approaches to strategy. Managerial and Decision Economics, 24: 253-266.

Spulber, D. F. 2009. The theory of the firm. New York: Cambridge University Press.

Stiglitz, J., \& Weiss, A. 1981. Credit rationing in markets with imperfect information. American Economic Review, 71: 393-410. 
Tang, Z., \& Tang, J. 2012. Entrepreneurial orientation and SME performance in China's changing environment:

The moderating effects of strategies. Asia Pacific Journal of Management, 29: 409-431.

Trabold, H. 2002. Export intermediation: an empirical test of Peng and Ilinitch. Journal of International

Business Studies, 33: 327-344.

Venkataraman, S. 1997. The Distinctive Domain of Entrepreneurship Research: An Editor's Perspective.

Advances in Entrepreneurship. in J. Katz and R. Brockhaus (eds.). Greenwich, JAI Press. 3: 119-138.

von Mises, L. 1949. Human action: A treatise on economics. New Haven, CT: Yale University Press.

Wasserman, N. 2002. The venture capitalist as entrepreneur: The characteristics and dynamics within VC firms.

Unpublished doctoral dissertation, Harvard University: Cambridge, MA.

Williamson, O. E. 1985. The economic institutions of capitalism. New York: Free Press.

Williamson, O. E. 1999. Strategy research: governance and competence perspectives. Strategic Management Journal, 20: 1087-1108.

Wood, M. S., \& McKinley, W. 2010. The production of entrepreneurial opportunity: a constructivist perspective. Strategic Entrepreneurship Journal, 4: 66-84.

Wright, M. 2007. Venture capital in China: a view from Europe. Asia Pacific Journal of Management, 24: 269282.

Wright, M., Robbie, K., \& Ennew K. 1997.Venture capitalists and serial entrepreneurs. Journal of Business Venturing, 12: 227-49.

Yamakawa, Y., Khavul, S., Peng, M. W., \& Deeds, D. 2013. Venturing from emerging economies. Strategic Entrepreneurship Journal (in press).

Yamakawa, Y., Peng, M. W., \& Deeds D. 2008. What drives new ventures to internationalize from emerging to developed economies? Entrepreneurship Theory and Practice, 32(1): 59-82.

Yang, X., Ho, E., \& Chang, A. 2012. Integrating the resource-based view and transaction cost economics in immigrant business performance. Asia Pacific Journal of Management, 29: 753-772.

Zacharakis, A., \& Shepherd, D. 2001. The nature of information and overconfidence on venture capitalists' decision making. Journal of Business Venturing, 16: 311-332.

Zhang, Y., \& Li, H. 2010. Innovation search in new ventures in a technology cluster: the role of ties with service intermediaries. Strategic Management Journal, 31: 88-109.

Zimmerman, M., \& Zeitz G. 2002. Beyond survival: achieving new venture growth by building legitimacy. Academy of Management Review, 27: 414-431. 
Figure 1. Entrepreneurs as intermediaries under information asymmetries

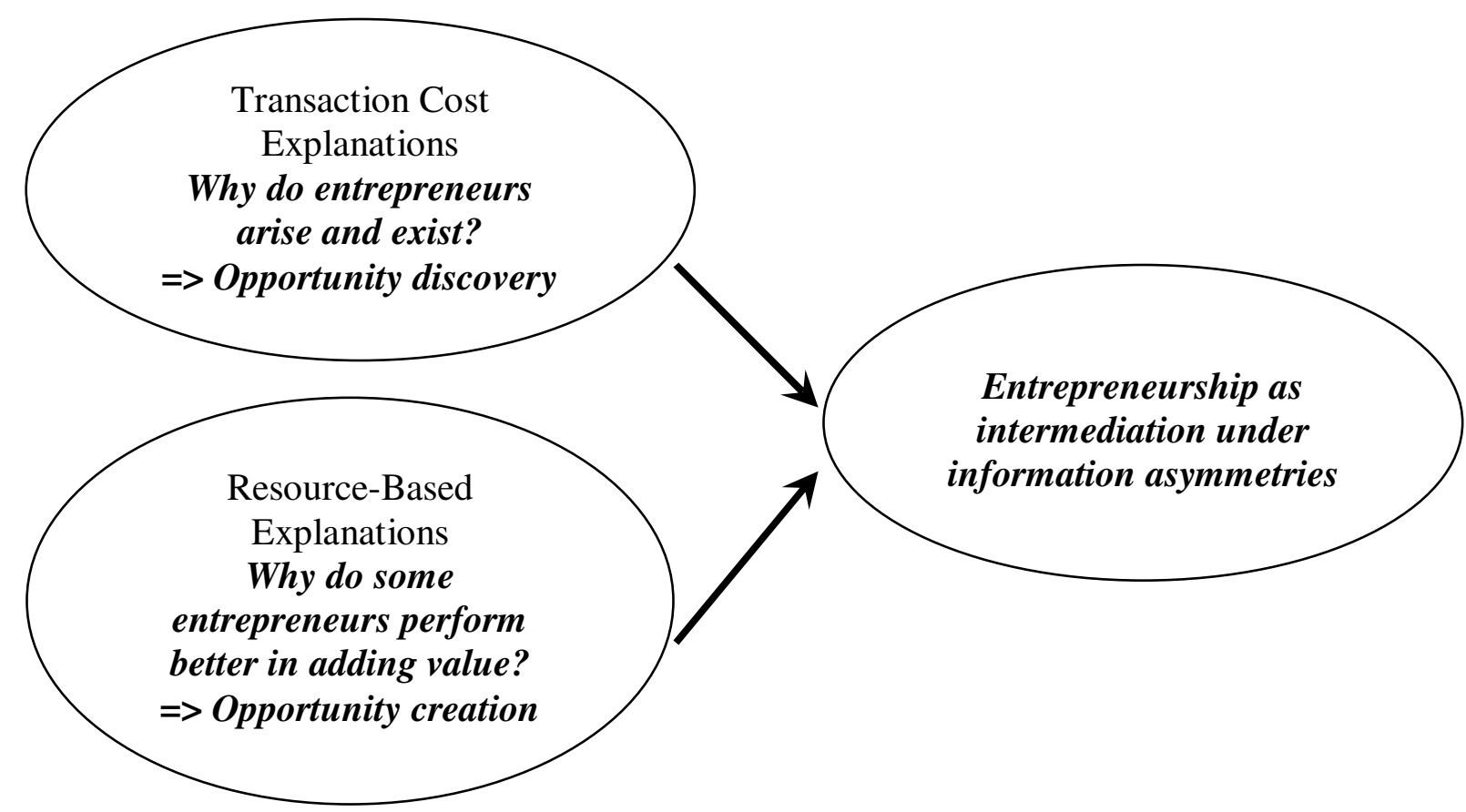

Figure 2a. Information asymmetries between buyers and sellers

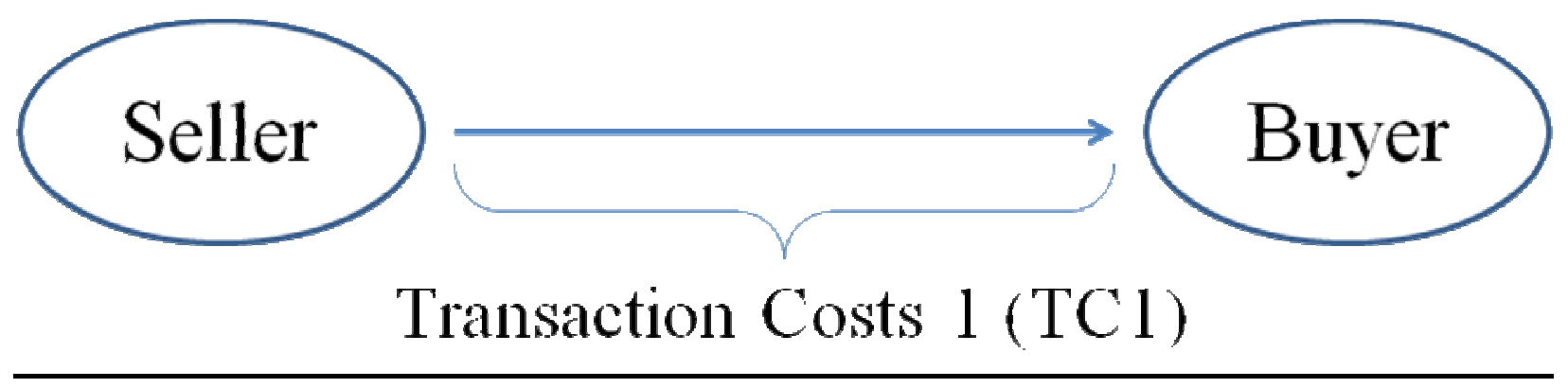

Figure 2b. Information asymmetries between entrepreneurs and transaction parties

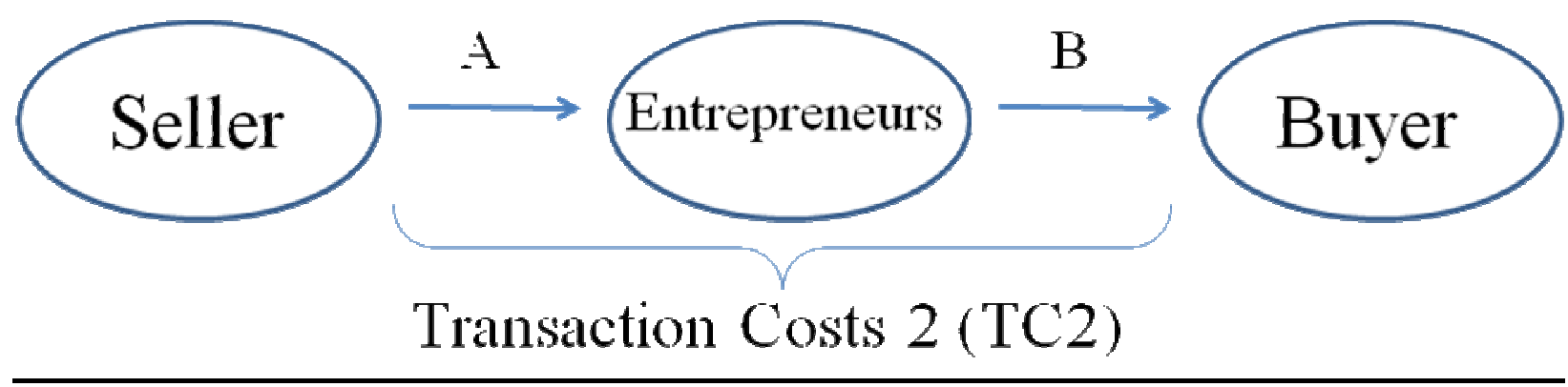

